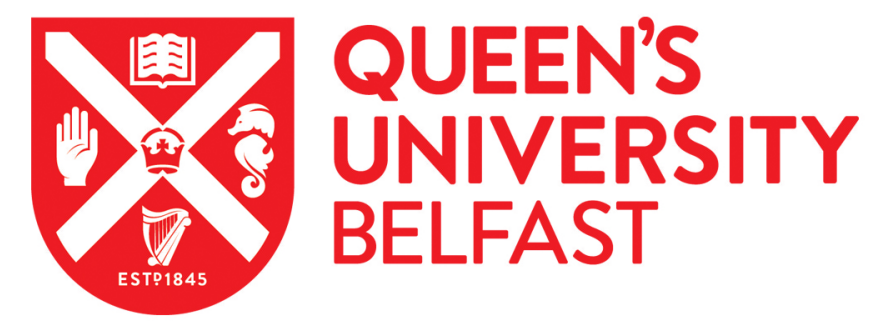

\title{
The Scottish Reformations and the Origin of Religious and Civil Liberty in Britain and Ireland: Presbyterian Interpretations, c.1800-60
}

Holmes, A. (2014). The Scottish Reformations and the Origin of Religious and Civil Liberty in Britain and Ireland: Presbyterian Interpretations, c.1800-60. Bulletin of the John Rylands Library, 90(1), 135-54.

https://doi.org/10.7227/BJRL.90.1.7

Published in:

Bulletin of the John Rylands Library

Document Version:

Peer reviewed version

Queen's University Belfast - Research Portal:

Link to publication record in Queen's University Belfast Research Portal

\section{Publisher rights}

The definitive, peer-reviewed and edited version of this article is published in:

A. Holmes, 2014, The Scottish Reformations and the Origin of Religious and Civil Liberty in Britain and Ireland: Presbyterian Interpretations, c.1800-60, Bulletin of the John Rylands Library, 90:1, 135-153, DOI: http://dx.doi.org/10.7227/BJRL.90.1.7

(C) 2014 Author. Published by Manchester University Press.

\section{General rights}

Copyright for the publications made accessible via the Queen's University Belfast Research Portal is retained by the author(s) and / or other copyright owners and it is a condition of accessing these publications that users recognise and abide by the legal requirements associated with these rights.

Take down policy

The Research Portal is Queen's institutional repository that provides access to Queen's research output. Every effort has been made to ensure that content in the Research Portal does not infringe any person's rights, or applicable UK laws. If you discover content in the Research Portal that you believe breaches copyright or violates any law, please contact openaccess@qub.ac.uk. 
The Scottish Reformations and the origin of religious and civil liberty in Britain and Ireland: Presbyterian interpretations, c. 1800-1860*

\section{Dr Andrew R. Holmes}

Queen’s University Belfast

During the first half of the nineteenth century, Presbyterian evangelicals in the Church of Scotland and the Synod of Ulster, the largest Presbyterian grouping in Ireland, wanted to return their churches to the Reformed theology, Presbyterian ecclesiology, and missionary activism of the Scottish Reformations. They stressed their commitment to Calvinist evangelicalism and had increasingly decided views on church-state relations and their duty to defend religious principle in the political arena. They held that the state had a duty to uphold true religion, that Christ alone was the head of the Church, and that the church had 'spiritual independence' from state interference. It was the tension between these principles, and the state's assault on spiritual independence, which led to the Disruption of the Church of Scotland in May 1843. In addition to these religious themes, it was claimed that Presbyterianism shaped the character of Scots and Ulster Scots by instilling the principles of religion, education, industry, and liberty, and thus contributing to the economic prowess of both areas. Furthermore, there developed on both sides of the North Channel a distinctive Presbyterian version of a Whig British identity, which asserted that religious and civil liberty in Britain and Ireland was established by John Knox in the sixteenth century, developed by the Covenanters in the seventeenth, and confirmed at the Glorious Revolution. These religious and political principles were defended against the traditional enemies of Presbyterians - Catholics, Episcopalians, and Erastian English politicians. This was a British and unionist narrative, but one that also asserted Scottish and Ulster-Scottish distinctiveness within the United Kingdom.

Excellent work by J.J. Coleman and Neil Forsyth has demonstrated how these themes became central to Scottish identity in the nineteenth century. ${ }^{1}$ Forsyth demonstrates how the 'nineteenth century saw the revival and widespread propagation in Scotland of a view of Scottish history that put Presbyterianism at the heart of the nation's identity, and told the story of Scotland's history largely in terms of the church's struggle for religious and constitutional

\footnotetext{
* I am most grateful to Robert Armstrong, Colin Kidd, and the two anonymous readers for their valuable comments on an earlier draft of this article. I would especially like to acknowledge the invaluable help of James Coleman who shared with me his extensive knowledge of commemorations in nineteenth-century Scotland.

${ }^{1}$ J.J. Coleman, 'The double-life of the Scottish past: discourses of commemoration in nineteenthcentury Scotland' (University of Glasgow PhD thesis, 2005).
} 
liberty' ${ }^{2}$ Both writers confined their discussion to Presbyterians in Scotland, but the same interpretation of the Scottish Reformations was expressed by the Presbyterians of Ulster who styled themselves as the first daughter of the Scottish Church. ${ }^{3}$ Richard Smyth, Irish Presbyterian minister, professor of theology at Magee College, Derry, and sometime Liberal MP for County Londonderry, stated in 1872 that 'it may be safely affirmed that nowhere in the world, either in Scotland or out of it, is the memory of those who, in the seventeenth century, contended for faith and liberty, more sacredly cherished than among their descendants in Ulster'. ${ }^{4}$ This sense of shared origins is significant because Presbyterians were a minority in Ireland, and dissenters from the Established Church of Ireland, whereas they were the dominant religious culture in Scotland. As a consequence, it is important to explore why both groups developed the same narrative of their historical development and identity. This is especially the case as the salience and popularity of Presbyterian interpretations of the early-modern period have not been widely appreciated by scholars of nineteenth-century Scottish or Ulster Scottish culture. It questions the prominence given to Sir Walter Scott and his unflattering descriptions of early-modern Presbyterians in his Waverley novels, especially Old Morality (1816). ${ }^{5}$ Scott's interpretation was vigorously challenged by other Scottish literary figures such as James Hogg and John Galt who reflected the sense of pride felt by most Scots in their Presbyterian forbearers. ${ }^{6}$

Though scholars following Linda Colley have pointed out how common Protestantism produced a British identity by bringing together English Anglicans and Scottish Presbyterians, Colin Kidd has rightly observed that these intra-protestant tensions retained their salience into the nineteenth century and how, in many ways, 'Protestant religion was the grit in the Union, not its glue'. ${ }^{7}$ The same is true of Irish Presbyterians who had been at the vanguard of radical politics in the 1790s and taken up arms against the ascendancy of the Church of Ireland during the 1798 rebellion. It has long been assumed that the pressure of the

${ }^{2}$ G. N. Forsyth, 'The Presbyterian interpretation of Scottish history, 1800-1914', (University of Stirling Ph.D. thesis, 2003); Neil Forsyth, 'Presbyterian historians and the Scottish invention of British liberty', Records of the Scottish Church History Society 34 (2004), 91-110.

${ }^{3}$ A.R. Holmes, 'Presbyterian religion, historiography and Ulster Scots identity, c. 1800 to 1914', Historical Journal 52 (2009), 615-40; and 'Irish Presbyterian commemorations of their Scottish past, $c$. 1830 to 1914', in Ireland and Scotland in the Nineteenth Century, eds. James McConnel and Frank Ferguson (Dublin, 2009), 48-61.

${ }^{4}$ Richard Smyth, 'The life and times of Dr Henry Cooke', British and Foreign Evangelical Review, 21 (1872), 238.

${ }^{5}$ Fiona Robertson, 'Walter Scott', in Susan Manning, Ian Brown, Thomas Owen Clancy, and Murray Pittock (eds.), The Edinburgh History of Scottish Literature - Volume two: Enlightenment, Britain and Empire (1707-1918) (Edinburgh, 2007), 183-90; Kidd, Subverting Scotland's past, 247-67.

${ }^{6}$ Beth Dickson, 'Sir Walter Scott and the limits of toleration', Scottish Literary Journal, 18:2 (Nov. 1991), 46-62; Ian Duncan and Douglas Mack, 'Hogg, Gault, Scott and their milieu’, in Manning et al, Edinburgh History, 211-20; Crawford Gribben, 'James Hogg, Scottish Calvinism and literary theory’, Scottish Studies Review, 5: 2 (2004), 9-26.

${ }^{7}$ Colin Kidd, Union and unionisms: political thought in Scotland, 1500-2000 (Cambridge: Cambridge University Press, 2008), 211. 
Catholic majority in Ireland and the rise of evangelicalism led inevitably to unity between Church of Ireland and Presbyterian protestants in the nineteenth century. Yet this policy of protestant unity, championed so forcefully by Henry Cooke, was not accepted by the clear majority of Presbyterian ministers and a substantial proportion of the laity who used the memory of the Scottish Reformations to protest at the errors and continued ascendancy of the Church of Ireland. ${ }^{8}$

In order to trace these various themes, this article is divided into three sections. The first provides a discussion of the eighteenth-century context and the revival of Presbyterian historiography in the early nineteenth century. Special attention will be devoted to the work of Thomas McCrie and how his interpretation of the Scottish Reformations provided theological and historical support for the evangelical party in the Church of Scotland in their various conflicts with Moderates, voluntaryists, Catholics, Episcopalian ritualists, and the British state. The second section charts the development of Presbyterian unity in response to the upheavals of the 1830s, especially the rise of Catholic self-confidence. It notes the importance of the Irish equivalent of McCrie, James Seaton Reid, and how the Scottish Second Reformation was seen as an ideal basis for Presbyterian unity in the nineteenth century, especially during the bicentenary of the Glasgow Assembly in 1838. The final section looks at how this theme of Presbyterian unity was articulated after the Disruption during the bicentenary commemoration of the Westminster Assembly in 1843 and the tercentenary of the first Scottish Reformation in 1860.

I.

The first Scottish Reformation began in 1560 and was a protestant reformation against Catholicism. ${ }^{9}$ Under the leadership of John Knox, and in opposition to the Crown, churchmen and nobles rejected Catholic doctrine and papal supremacy over the Scottish Church. Over the next decades, many Scots became convinced that the Presbyterian form of church government most closely approximated with the teachings of the Bible. It was in this context that Presbyterianism came to the north of Ireland with the arrival of Scottish settlers to Ulster in the early years of the seventeenth century. Scottish ministers gradually found employment in the established Church of Ireland, but this uneasy toleration of Presbyterians ended in the 1630s when Charles I attempted to impose religious uniformity throughout his three

\footnotetext{
${ }^{8}$ A.R. Holmes, 'Covenanter politics: evangelicalism, political liberalism, and Ulster Presbyterians, 1798-1914’, English Historical Review cxxv (2010), 340-69.

${ }^{9}$ The following paragraph is based on: Robert Armstrong, 'Ireland's Puritan revolution? The emergence of Ulster Presbyterianism reconsidered’, English Historical Review cxxi (2006), 1048-74; J.E.A. Dawson, Scotland re-formed, 1488-1587, The new Edinburgh History of Scotland, 6 (Edinburgh: Edinburgh University Press, 2007); David Stevenson, Scottish covenanters and Irish confederates: Scottish-Irish relations in the mid-seventeenth century (Belfast: Ulster Historical Foundation, 1981).
} 
kingdoms under the authority of bishops. As a consequence, the so-called Second Reformation in defence of Presbyterianism in Scotland began in 1638 with the signing of the National Covenant and the meeting of the General Assembly in Glasgow in December. When Irish Catholics rose in rebellion in 1641, a Scottish army was dispatched to Ulster and the chaplains who accompanied the regiments established the first presbytery in Ireland in June 1642. Owing to this and other factors, the Second Reformation became a movement to unite Britain and Ireland under a common religious system when Scottish and English opponents of Charles I signed the Solemn League and Covenant in 1643. Scots saw this as embodying a commitment to establishing a Presbyterian state in Britain and Ireland whereas the English saw it as a military alliance, though the agreement did lead to the calling of the Westminster Assembly of Divines from 1643 to 1647 that produced the doctrinal standards of Presbyterianism, the Westminster Confession of Faith and the Larger and Shorter Catechisms. Despite continued opposition in both kingdoms from Oliver Cromwell and the postRestoration Stuart monarchy, Presbyterianism managed to consolidate and grow between the Restoration and the Revolution. In 1690 the Church of Scotland emerged as Presbyterian and had its status secured by the 1707 Act of Union. ${ }^{10}$ Presbyterians in Ulster consolidated a separate ecclesiastical and political identity through the establishment of congregations, presbyteries, and the General Synod of Ulster in $1690 .{ }^{11}$ Unlike in Scotland, Presbyterians in Ulster found themselves in an Anglican confessional state, excluded from full access to civil society, though they continued to receive a state subsidy, the regium donum. ${ }^{12}$ During the eighteenth century, the majority of Presbyterians would remain committed to the doctrines and structures of seventeenth-century Presbyterianism, but moderate theological opinion became influential in both Scotland and Ulster. An important aspect of this moderate Presbyterianism was an Enlightenment historiography that sought to downplay the upheavals and radicalism of the sixteenth and seventeenth century and to emphasise the importance of improvement through the British connection and the application of Whig principles. ${ }^{13}$ This led to a disjunction between the interpretation offered by philosophical historians, such as William Robertson and David Hume, and the popular memory of the Covenanters amongst conservative ministers and lay Presbyterians in both countries. This popular commitment was an important factor in the success of various secession movements in Scotland and Ulster,

\footnotetext{
${ }^{10}$ David Allan, Scotland in the eighteenth century: union and enlightenment (Harlow, 2001), 40-4.

${ }^{11}$ Raymond Gillespie, 'The Presbyterian revolution in Ulster, 1600-1690', in The churches, Ireland and the Irish (Studies in Church History, xxv), eds. W.J. Sheils and Diana Wood (Oxford: Blackwell, 1989), 159-70.

${ }^{12}$ I.R. McBride, Scripture politics: Ulster Presbyterians and Irish radicalism in the late eighteenth century (Oxford: Clarendon Press, 1998).

${ }^{13}$ Colin Kidd, Subverting Scotland's past: Scottish Whig historians and the creation of an AngloBritish identity (Cambridge, 1993); I.R. McBride, 'Ulster Presbyterians and the confessional state, c. 1688-1733', in Political discourse in seventeenth- and eighteenth-century Ireland, eds. D. G. Boyce, Robert Eccleshall and Vincent Geoghegan (Basingstoke: Palgrave, 2001), 169-92.
} 
especially the Seceders who left the Church of Scotland in 1733 in protest at patronage and an alleged weakening of commitment to Calvinist theology. ${ }^{14}$

In reaction to the influence of this moderate theological outlook, Presbyterianism in both areas was deeply influenced by the rise to prominence of evangelicalism in the 1790s and underwent a far-reaching process of religious reform and revival during the first half of the nineteenth century. ${ }^{15}$ The Presbyterian evangelicals in both countries who spearheaded this reformation in the 1820s and 1830s wanted to return their churches to the principles and ethos of the Scottish Reformations as a means of bringing about the millennial reign of Christ on earth. In Scotland the process of reform contributed to the worsening of relations between the British state and the evangelical party within the Established Church of Scotland, led by Thomas Chalmers, over the spiritual independence of the church. The dispute reached a decisive climax in the Disruption of May 1843 when over 450 minsters and around fortypercent of the lay members of the Established Church withdrew to form the Free Church of Scotland. In Ulster the movement for reform within Presbyterianism led to union, not disruption, with the unification of the Synod of Ulster and the Seceders to form the General Assembly of the Presbyterian Church in Ireland in 1840. Reform began in the 1820s under the leadership of Henry Cooke, the most prominent Irish Presbyterian of the period, and resulted in the expulsion of a number of Arian and non-subscribing ministers from the Synod of Ulster in 1829. Despite these different trajectories, Scottish and Irish Presbyterians believed that they were continuing in their own day the struggle against the same age-old enemies of Presbyterianism, namely, prelacy, popery, and English politicians.

The widespread desire to return to the values and example of the Scottish Reformations owed much to the emergence of a distinctive Presbyterian historiography. This nineteenth-century revival built upon and extended the interpretations offered by earlymodern historians such as George Buchanan, David Calderwood, John Row, James Kirkton, and Knox himself. It was continued in the literature of the later Covenanters, including Sir James Steuart's Naphtali (1667), Alexander Shields A Hind Let Loose (1687), and the anonymous A Cloud of Witnesses (1714). ${ }^{16}$ As noted, this narrative had remained popular amongst lay Presbyterians and it is significant that the revival of interest in the Scottish Reformations came from within one of the smallest secession bodies who shared this interpretation. Thomas McCrie belonged to the tiny Auld Licht Anti-Burgher Secession,

\footnotetext{
${ }^{14}$ C.G. Brown, Religion and society in Scotland since 1707 (Edinburgh: Edinburgh University Press, 1997), 18-25, 78-83; David Stewart, The Seceders in Ireland, with annals of their congregations (Belfast: Presbyterian Historical Society of Ireland, 1950).

${ }^{15}$ S. J. Brown, Thomas Chalmers and the godly commonwealth in Scotland (Oxford: Oxford University Press, 1982); idem., The national churches of England, Ireland, and Scotland 1801-46 (Oxford: Oxford University Press, 2001); A. R. Holmes, The shaping of Ulster Presbyterian belief and practice, 1770 to 1840 (Oxford: Oxford University Press, 2006).

${ }^{16}$ Forsyth, 'Presbyterian interpretation', 12-15.
} 
which was formed in 1806 after a dispute over so-called modernising trends that weakened the Anti-Burghers commitment to the principle of an established church. ${ }^{17}$ The Auld Lichts traced their origins back to the original Secession from the Church of Scotland in 1733 and were theologically conservative and historically conscious. As a consequence, McCrie used historical scholarship as a means of justifying the truth as understood by himself and his cobelligerents. According to a review of his posthumous sermons in the 1836 edition of the Presbyterian Review, a periodical of the evangelical party in the Church of Scotland, 'We are inclined ... to believe that he was attracted to the subjects of his biographical works, rather by the opportunity which they afforded him of exhibiting and vindicating certain important principles, than by the variety of incident, and diversity of interesting character which they enabled him to bring into view.' 18

McCrie made his reputation with The Life of John Knox (1812), which was an instant success. In the preface to the 1855 edition, his son noted 'the complete success which has crowned this first acknowledged effort of the Author in the field of History' and 'its gradual and growing influence in moulding the sentiments of thousands of readers, and in resuscitating the spirit and principles of our Reformation' ${ }^{19}$ In the preface to the first edition of 1812, McCrie had noted that the 'Reformation from Popery marks an epoch unquestionably the most important in the history of modern Europe' for it affected every aspect of modern life. ${ }^{20}$ Though McCrie rejoiced in the Reformation in general, he believed that the Scottish Reformation was the most complete and scriptural. He underlined this point by contrasting the thorough Scottish Reformation with the English version that had been disfigured by erastianism, prelacy, and liturgy. ${ }^{21}$ Furthermore, McCrie upheld the Whig Presbyterian view that it was the Reformation that brought about British liberty and not the Union of 1707 as Robertson and other eighteenth-century Moderates had claimed. By resisting the tyranny represented by the papacy and Mary, Queen of Scots, Knox articulated the basis of modern British religious and civil liberty. McCrie returned to this Whig Presbyterian interpretation of the Scottish Reformation in his second major work, a biography of Andrew Melville, which appeared in November 1819. Both biographies became, according to the Edinburgh Christian Instructor, 'the Iliad and Odyssey of the Scottish Church'. ${ }^{22}$ McCrie noted that Melville's life did not have the dramatic backdrop of the Reformation, but he nevertheless played a crucial role in the vindication of Presbyterian rights and principles.

\footnotetext{
${ }^{17}$ James Kirk, 'McCrie, Thomas (1772-1835)’, Oxford Dictionary of National Biography (Oxford: Oxford University Press, 2004).

18 'McCrie’s Sermons', Presbyterian Review 8 (Mar. 1836), 80

19 'Life of John Knox', The works of Thomas McCrie, ed. Thomas McCrie junior, new edn. 4 vols. (Edinburgh, 1855-7), i. iv.

${ }^{20}$ Ibid., vii.

${ }^{21}$ Ibid., 50.

${ }^{22}$ Cited in Forsyth, 'Presbyterian interpretation', 96
} 
In particular, the Act of 1592 passed by the Scottish Parliament that ratified the Presbyterian constitution of the Church of Scotland legally secured 'the religious privileges of the nation against arbitrary encroachments' and 'pointed out the propriety and practicability of providing similar securities in behalf of political rights'. ${ }^{23}$ McCrie continued his defence of the Scottish Reformations in 1817 with an effective review of Sir Walter Scott's portrayal of the later Covenanters in his Waverley novels. McCrie contrasted Scott's description with the popular memory held by the 'good people of Scotland' who would 'be amazed to see those whom they have been accustomed to revere as patriots, and to venerate as confessors and martyrs for truth, now held up to derision as mad enthusiasts, and reviled as hypocritical and murderous ruffians' ${ }^{24}$ The later Covenanters of the late seventeenth century were subsumed in McCrie's narrative of religious and civil liberty, and the distinction between mainstream and radical Presbyterians in this period is almost non-existent. 'What we assert is (and we make the assertion without the slightest fear of refutation), that, in opposing Prelacy, Erastianism, and the Indulgence, the Covenanters were standing up for the civil rights and political liberty of their country. ${ }^{25}$

McCrie's interpretation of the Scottish Reformations quickly became the standard because the majority of the Scottish population were Whig-Liberal Presbyterians who were eager to read accounts that confirmed their views. ${ }^{26}$ Popular expressions of reverence for the Scottish Reformations can be seen in the monument erected to Knox in Glasgow in 1825 and the on-going memorialisation of the Covenanter martyrs of the later seventeenth century by Reformed Presbyterians who claimed lineal descent from them. ${ }^{27}$ Yet the key to McCrie's success was his influence upon evangelicals within the Church of Scotland. By portraying the Scottish Reformations as upholding the principles of non-intrusion, church establishments, and the spiritual independence of the Church, he was providing theological and historical support for the evangelical party in their various conflicts with Moderates, voluntaryists, Catholics, Episcopalian ritualists, and Erastian British statesmen. Significantly, one of the last public engagements of McCrie's career was to provide expert testimony before a select committee of the House of Commons on the patronage question in the Church of Scotland in $1834 .^{28}$ The Presbyterian Review noted that the main principle of his Life of Melville was that 'there are duties which the state owes to the religion of Christ, and privileges which it can confer on His church, without infringing on the independence of that church, or interfering

\footnotetext{
23 'Life of Andrew Melville', Works of McCrie (1857), ii. 149.

24 'A Review of “Tales of My Landlord”', Works of McCrie (1857), iv. 47.

${ }^{25}$ Ibid., 110.

${ }^{26}$ Forsyth, 'Presbyterian interpretation', 96-8.

${ }^{27}$ Coleman, 'Double-life of the Scottish past', 157-65, 273-8.

${ }^{28}$ Report from the Select Committee of the House of Commons appointed to consider the past and present state of he Law of Church Patronage in Scotland, 1834 (512), v. 355-93.
} 
with its spiritual functions' ${ }^{29}$ In October 1841 the same periodical observed, 'Much - very much - of the sound ecclesiastical principles, now lifting up their front again amongst us, is to be attributed to the biographer of Knox and Melville', and lamented the influence of the 'sickly sentimentalism, perverted taste, contempt of religion, and indecent profanity' of Scott and his fellow novelists. ${ }^{30}$ Robert Smith Candlish, a principal leader of the Free Church, numbered McCrie as one of the key formative influences on his life along with Andrew Thomson and Thomas Chalmers. According to Candlish’s biographer, William Wilson, ‘To Dr. M'Crie more than to any other we owe it that so many of the people of Scotland clearly apprehended the doctrine of the Church's autonomy, and recognised her obligation to act out what she had ascertained to be the will of her great living Head irrespective of what secular and civil authorities might do and determine.' By his publications, 'Dr McCrie ... created a new era in ecclesiastical affairs'. ${ }^{31}$ McCrie also inspired evangelical and non-intrusion histories of the Church of Scotland by James Aikman, William Sime, Thomas McCrie junior, and William Maxwell Hetherington. ${ }^{32}$

II.

The growing tensions in the Church of Scotland between Moderates and evangelicals, and the standoff between the British state and the evangelical party, led many Scottish Presbyterians to seek support from their co-religionists in the north of Ireland. Presbyterian evangelicals in Ulster were promoting a similar process of reformation that was inspired by their understanding of seventeenth-century Presbyterianism. When McCrie died in 1835, the Synod of Ulster took the unprecedented step of passing a unanimous resolution mourning his death and lamenting that 'he has been removed from the church at this particular crisis, when his services, as the historian and defender of the Reformation, were more than ever needed'. ${ }^{33}$ The Irish Presbyterian equivalent of McCrie was James Seaton Reid, sometime minister of the Synod of Ulster, professor of ecclesiastical history, church government, and pastoral theology for the Synod, and regius professor of ecclesiastical and civil history at the University of Glasgow from 1841 to $1851 .{ }^{34}$ Reid is best known for his three-volume History of the Presbyterian Church in Ireland, volume one of which was published in 1834, volume two in 1837, and volume three completed in 1853 by his successor in Belfast, W. D. Killen. ${ }^{35}$

\footnotetext{
29 'McCrie's Sermons', 82.

30 'Miscellaneous writings (1841)', Presbyterian Review, 14 (Oct 1841), 534.

${ }^{31}$ William Wilson, Memorials of Robert Smith Candlish, D.D., minister of St. George's Free Church, and principal of the New College, Edinburgh (Edinburgh, 1880), 27, 29.

${ }^{32}$ Forsyth, 'Presbyterian interpretation', 117-28.

${ }^{33}$ Minutes of a General Synod, held at Belfast, 1835 (Belfast, 1835), 76.

${ }^{34}$ Robert Allen, James Seaton Reid: a centenary biography (Belfast, 1951).

${ }^{35}$ Subsequent references will be taken from the 1867 edition, History of the Presbyterian Church in Ireland, ed. W. D. Killen (3 vols., 2nd edn., Belfast, 1867).
} 
Reid concurred with McCrie's commitment to the Reformed theology of seventeenth-century Scottish Presbyterianism, his high estimation of the character of those reformers, the superiority of the Scottish Reformation over the Episcopalian and erastian reformations in England and Ireland, and the indispensible role of Presbyterians in the constitutional development of the United Kingdom. 'Their history', he wrote in the preface to Volume One, 'is so intimately connected with all the more important changes in the civil affairs of Great Britain during the last two centuries, and the cause of constitutional freedom is so much indebted to their noble efforts at the [Williamite] Revolution'. He also noted that their influence had made Ulster peaceful and prosperous compared to the rest of Ireland and that they 'have been so generally characterised by probity, peaceableness, and industry, as well as an enlightened attachment to the principles of civil and religious liberty'. ${ }^{36}$ Reid's History was well-reviewed in the Presbyterian Review, which highlighted the theme of Presbyterian unity: 'In all the transactions of Scotland with Ireland, civil and ecclesiastical, we see an union of decision and moderation, of heartfelt interest in the party in Ulster which espoused the Scottish policy, and delicacy of feeling in the assistance they furnished; of cordiality without officiousness, and zeal without indiscretion, which looks well on the pages of history, and which we trust will be imitated in our own day by our future Assemblies. ${ }^{37}$

The publication of Reid's work came at a time when the General Assembly of the Church of Scotland was considering renewing ministerial communion with the Synod of Ulster. This had been severed in 1818 after the General Assembly refused to clarify its Declaratory Act of 1799 about unqualified ministers and preachers, which had the effect of excluding from Scottish pulpits Presbyterian ministers from Ireland. Evangelicals in the Church of Scotland considered it time to reinstate the connection owing to the continued links between both communities and the measures taken by the Synod of Ulster to ensure orthodoxy. Scottish evangelicals noted that Presbyterianism in Ulster was 'an actual branch of our own church' and were 'disposed to rest much on the common origin and long-cherished communion of the two churches. The very troubles through which they together passed strengthen the moral tie which binds them together.' In addition to historic ties, there were more immediate reasons for reunion as the 'present is a very important period in the religious history of this country'. In particular, the conversion of Catholic Ireland to evangelical Protestantism was seen as essential to the future peace of the United Kingdom. ${ }^{38}$ The consummation of renewed communion occurred at the annual meeting of the General Assembly in $1836 .{ }^{39}$ As part of the Irish delegation, Henry Cooke addressed the Assembly

\footnotetext{
${ }^{36}$ Ibid., i. iii-iv.

37 'Dr Reid’s Ulster Church’, Presbyterian Review 5 (Sept. 1834), 642.

38 'Renewed communion with the Synod of Ulster', Presbyterian Review 6 (Mar 1835), 304-27, quotations from 325, 326.

39 'Proceedings of the General Assembly’, Presbyterian Review 8 (July 1836), 380-2, 431-9.
} 
and dutifully acknowledged 'our Mother Church of Scotland' and defended the principle of established churches and the regium donum. Cooke vindicated the record of Scottish Presbyterians in Ulster from the seventeenth century who had brought loyalty, peace, and prosperity to the most rebellious and backward of Irish provinces. He concluded by remarking, 'After years of separation, we are re-united; and, though in different lands, and in different outward circumstances, we form, in spirit and communion, one Presbyterian Church. ${ }^{40}$

Presbyterians in Scotland and Ireland saw in the Scottish Reformations the basis of Presbyterian union. In addition to a commitment to confessional theology, all Presbyterian writers contrasted Scottish and Ulster Scots support for civil and religious liberty in the 1630s and 1640s with popish tyranny and prelatic persecution. This struggle was demonstrated with particular clarity in their discussion of the Solemn League and Covenant of 1643. In a sermon preached in 1821, McCrie asked his audience to consider the beneficial impact to Britain and Ireland if the Solemn League and the plan recommended by the Westminster Assembly had been allowed to develop.

Of what benefit might it not have been before this day to unhappy Ireland, which has been perhaps more indebted to colonies from Scotland, and to the religion imported by them, than to any boon it has received from England! And would not great benefit have redounded from it to Scotland herself, whose ecclesiastical constitution and liberties, as well as the religious principles and habits of her people, have suffered so much formerly and of late, from her intimate connection with a country in which a system opposite in various respects to hers has been established?

For McCrie, this state of affairs was a matter of 'deepest regret' and he called for a testimony against the repudiation of the terms of the Covenant and a revival of the reformation it envisaged. ${ }^{41}$ Unlike McCrie, who seemed to be calling for a return to a national recognition of the Covenant, Reid admitted the document was a product of its time and that Presbyterians were no longer bound to honour it. ${ }^{42}$ Yet Reid enthused about the principles it enshrined and the results it produced in Scotland and Ireland. It 'ascertained and united the friends of civil and religious liberty' and gave them renewed confidence; it led to the extensive diffusion of Presbyterianism in Ireland and 'revived the cause of true religion and piety, which had lamentably declined under the iron sway of the prelates' and civil war; and it began a Second Reformation in Ulster that resulted in 'the improving manners and habits of society, and in the growing attention of the people to religious duties and ordinances' ${ }^{43}$ Hetherington agreed

\footnotetext{
${ }^{40}$ Henry Cooke, 'The Church of Scotland and the Synod of Ulster', Orthodox Presbyterian 7 (1836), 305-16, quotations from 312, 315.

41 'Two discourses on the unity of the Church (1821)', Works of McCrie (1857), iv. 193.

${ }^{42}$ Reid, History, ii. 410-12.

${ }^{43}$ Ibid., 456.
} 
that despite its critics there was no doubt that on the Covenant 'mainly rests, under Providence, the noble structure of the British constitution. But for it, so far as man may judge, these kingdoms would have been placed beneath the deadening bondage of absolute despotism; and in the fate of Britain, the liberty and civilization of the world would have sustained a fatal paralyzing shock.' The constitutional implications may have been startling, but the Christian ought to see biblical principles at work. Revealing his commitment to millennial eschatology, Hetherington claimed that these principles would transform Britain and Ireland in accordance with 'the glorious predictions of inspired Scripture', which foretold a time 'when all the kingdoms of this earth shall become the kingdoms of Jehovah and of his Anointed, and all shall be united in one Solemn League and Covenant under the King of kings and Lord of lords'. ${ }^{44}$

The interpretation of the Scottish Reformations articulated by Presbyterians in both countries was clearly expressed during the bicentenary commemorations of the Glasgow General Assembly in December 1838. Meetings were held throughout Scotland, though the Edinburgh meeting 'was by far the most prominent and controversial'. ${ }^{45}$ It was dominated by representatives of the so-called Wild Party, a younger generation of evangelicals within the Church of Scotland, such as William Cunningham, Thomas Guthrie, James Begg, and Candlish, who used the meeting to protest against state interference. The Presbyterian Review noted, 'In Glasgow this festival was kept with more of eclat and official countenance; - in Edinburgh, as we venture to think, on the part of conductors, with more of the true spirit of that memorable Assembly. ${ }^{46}$ This belligerence had been prefigured the previous month at the inaugural meeting of the Tradesmen's Church Association in the city. This organisation sought and received support from the General Assembly's Church Extension Committee and its convenor, Thomas Chalmers, and their meeting covered, amongst other topics, dissent from the 'modern heresy of Voluntaryism'. One of the speeches was delivered by the Revd William Gibson of Ballybay, County Monaghan, who was on a fundraising tour to Scotland on behalf of the Home Mission of the Synod of Ulster. Gibson began by noting that his own denomination was 'the eldest daughter of the Church of Scotland' and called for unity of purpose between both denominations in their struggle for biblical truth under 'the old blue banner of the Reformation' ${ }^{47}$ Another Irish voice was heard in support of the Home Mission in Glasgow the same month when the Revd John Brown delivered a sermon in defence of the Covenanters in the Hope Street Gaelic church. Brown emphasised the Scottish and Irish

\footnotetext{
${ }^{44}$ W.M. Hetherington, A history of the Church of Scotland: from the introduction of Christianity to the meetings of the Commission of the General Assembly, in August 1841 (Edinburgh, 1842), 334-5.

${ }^{45}$ Coleman, 'Double-life of the Scottish past', 165-80, quotation at 166.

46 'Commemoration of the Assembly 1638', Presbyterian Review 11 (Jan. 1839), 576.

${ }^{47}$ Report of the great meeting of the trade and working classes, in support of the Church of Scotland, in the Assembly Room, George Street, Edinburgh, on Wednesday the 14th November 1838, second edition (Edinburgh, 1838), 5, 25-6.
} 
Presbyterian struggle for freedom against prelacy, arbitrary government, and oppression, and easily conflated the story of the Covenanters with that of the Glorious Revolution. He ended his sermon in millennial language with a call to Presbyterians in Scotland and Ireland to support one another 'as in former times' so that 'amidst our contendings against error, and our efforts to advance the truth, we shall remember each other before the throne of grace, and remain united under the same banner, until all nations shall enjoy a lasting jubilee, being subject to the Prince of Peace'. ${ }^{48}$

There was no doubt amongst those who compiled the official account of the December meeting in Edinburgh of the contemporary relevance of the Glasgow Assembly of 1638, especially 'the position at present occupied by the Church of Scotland in relation to the civil power'. The meeting asserted the simplicity of the constitution, discipline, and worship of the Scottish church in comparison with 'only half reformed' England, and protested at the resurgence of Catholicism in Britain and Ireland. The speeches focused on the principles to be learnt from events two-hundred years previously - spiritual independence, the abolition of prelacy, the parity of ministers, the establishment principle, education - and that Presbyterian truth was the bedrock of Scottish identity. Candlish believed that though the constitution of 1638 never 'had altogether fair play', especially during the previous century, the Presbyterian system had been in the main preserved and 'our country owes a deep debt of gratitude to Presbyterian government, insomuch that in the heart of a leal and true Scotsman, Patriotism and Presbyterianism are synonymous and identical'. Thomas Guthrie looked from the past to the future and saw 'a glorious day breaking on the mountains of Scotland' when 'God is again smiling on the church of our martyred fathers. The progress of reform in the last seven years has been as astonishing to the friends as it has been terrible to the foes of our church.' ${ }^{49}$

One of the most obvious foes of the resurgent Scottish church was Scottish Episcopalianism whose champions described the Covenanters as rebellious fanatics..$^{50}$ In turn, evangelicals interpreted these views in the context of the rise of Puseyism, the so-called Romeward trend within the Church of England, as 'just a device of Satan for injuring the cause of evangelical religion'. ${ }^{51}$ The need for protestant unity against the interconnected threats of Puseyism and popery was shared by Presbyterians in Ireland who, in the late 1830s and early 1840s, had to contend with a revival of High Church views within the Church of Ireland that led directly to the repudiation of the legal right of Presbyterian ministers to

\footnotetext{
${ }^{48}$ John Brown, 1638; or, the Covenanters; a sermon preached in Hope-Street Gaelic Church, Glasgow, on the 21st November, 1838 (Glasgow, 1839), 11, 24.

${ }^{49}$ Report of the great public meeting held in the Assembly Rooms, Edinburgh, on Thursday evening, Dec. 20, 1838, to commemorate the restoration of civil and religious liberty, and of Presbyterian church government, as secured by the Glasgow Assembly of 1638 (Edinburgh, 1838), 3, 38-9, 70. ${ }^{50}$ Coleman, 'Double-life of the Scottish past', 171-4.

51 'Commemoration of the Assembly 1638', Presbyterian Review 11 (Apr. 1839), 647.
} 
perform certain marriages because they were not episcopally ordained. ${ }^{52}$ This concern with the Puseyite threat to Presbyterian rights was reinforced by the problems confronting the Church of Scotland in the early 1840s and was widely advertised during the bicentenary commemoration on 14 June 1842 of the formation by Scottish ministers of the first presbytery in Ireland. ${ }^{53}$

III.

When the Disruption of the Church of Scotland occurred in May 1843, the newly-formed Free Church declared that they withdrew on the basis of the principles of the Scottish

Reformations. For their defence of the spiritual independence of the church and the principle of non-intrusion, the Irish General Assembly immediately recognised the Free Church 'alone as the legitimate representative of those from whom the Presbyterian Church in Ireland has always regarded it the noblest distinction to be descended' and only resumed formal links with the Church of Scotland in $1885 .{ }^{54}$ This interpretation was enshrined in the official history of the Disruption published in 1849 by Robert Buchannan who claimed that the conflict over the principles of the 'independence of the church in matters spiritual, and the rights of her christian people in the choice and settlement of their ministers' was at the heart of the Scottish Reformations. These had been assailed variously by 'the stern and selfish Regent Morton, by the fickle, mean, and crafty James VI., by the blindly obstinate and intolerant Charles I., and finally, by the headlong recklessness of the brothers Charles II. and James VII' who wanted erastian and prelatic ascendancy over the Church. ${ }^{55}$ This memory of the Scottish Reformations was also expressed at a local level. The Free Church collected various personal accounts of the Disruption that were eventually edited by Thomas Brown and published in 1878 as Annals of the Disruption. Brown noted that 'these historical associations exercised a powerful influence among the people of Scotland' owing to the widespread knowledge of the Covenanters gained from reading the Scots Worthies, The Cloud of Witnesses, and Foxe's Book of Martyrs. One respondent noted that the Scots Worthies reflected the principles of the Free Church, principles that were 'truly Scottish, as well as truly scriptural. They have been baptised by the sufferings and blood of our fathers, and this has doubly endeared them to me. ${ }^{56}$ Local associations with seventeenth-century Covenanters

\footnotetext{
${ }^{52}$ Holmes, 'Covenanter politics’, 349-51.

${ }^{53}$ Holmes, 'Irish Presbyterian commemorations', 54-5.

${ }^{54}$ Minutes of the General Assembly of the Presbyterian Church in Ireland [hereafter, MGA], i (1843), 220; vi (1885), 906-7.

${ }^{55}$ Robert Buchanan, The Ten Years' Conflict: being the history of the Disruption of the Church of Scotland, 2 vols. (Glasgow, 1849), i. 137.

${ }^{56}$ Thomas Brown (ed.), Annals of the Disruption: consisting chiefly of extracts from the autograph narratives of ministers who left the Scottish Establishment in 1843, 2 vols. (Edinburgh, 1878), i. 4.
} 
also played their part in places such as Bothwell Bridge, Airmoss, Drumclog, Greyfriars' churchyard in Edinburgh, and Muirkirk. ${ }^{57}$

The opportunity for the Free Church to gain historical and theological legitimacy from the Scottish Reformations came almost immediately with the bicentennial commemoration of the Westminster Assembly in July 1843. The meetings in Scotland were dominated by the Free Church and were used as a means of stressing Presbyterian unity on the basis of the Westminster Confession of Faith. As a consequence, the July meetings in Edinburgh had representatives from the United Secession, the Relief Church, the Original Secession, the Reformed Presbyterians, and English Presbyterianism. ${ }^{58}$ It was claimed that the decision to commemorate the Assembly was an opportunity to issue a rallying cry to those who upheld the doctrines of the Westminster Standards to resist the revival of popery, prelacy, and Erastianism in their own day. Chalmers noted that the Irish General Assembly and the Free Church were 'scarcely if at all distinguishable' from each other and that their shared identity meant that 'all those cases where we can work together, there seems not a single obstacle in the way of our most cordial and entire co-operation'. ${ }^{59}$ Chalmers's views reflected his admiration for the constitution of the Irish church that had full spiritual independence while also receiving a state grant in the form of the regium donum. ${ }^{60} \mathrm{In}$ addition to the Edinburgh event, public meetings across the United Kingdom were planned for 15 September and the Irish General Assembly directed meetings to be held in principal towns to commemorate the work of the Westminster Assembly and to show how it benefited both the Church and civil society. ${ }^{61}$

After 1843 the theme of unity on the basis of Presbyterian principles grew in importance in response to the renewed threat of Catholicism. The Free Church was especially associated with the intensification of organised anti-Catholicism after the Revd James Begg helped establish the Scottish Reformation Society in 1850. The acting secretary of the Society until 1858 was an Irish Presbyterian missionary, the Revd Edward Marcus Dill, and the Society soon had auxiliaries all over Scotland, except in Glasgow which had its own Glasgow Protestant Laymen's Association. The Scottish Reformation Society was founded against the backdrop of a desire for united action, yet it was never a mass movement and there were

\footnotetext{
${ }^{57}$ Ibid., i. 5-6; ii. 76-7.

${ }^{58}$ Coleman, 'Double-life of the Scottish past', 180-6.

${ }^{59}$ Bicentenary of the Assembly of divines at Westminster, held at Edinburgh, July 12th and 13th, 1843. Containing a full and authentic report of the addresses and observations. With an introductory sermon by Rev. Dr Symington (Edinburgh, 1843), 14, 89-90.

${ }^{60}$ See Chalmers address to the Irish Presbyterian delegation at the inaugural meeting of the Free Church, Banner of Ulster, 23 May 1843.

${ }^{61} M G A, \mathrm{v}$ (1843), 225.
} 
internal tensions between Churchmen and Free Churchmen over the establishment principle and national identity. ${ }^{62}$

The intensification of anti-Catholic attitudes found expression in the tercentenary of the Scottish Reformation in 1860. There were three distinct phases - the annual meetings of the various Presbyterian bodies in May, the meeting organised by the Scottish Reformation Society in August, and the national commemoration in December. ${ }^{63}$ The annual meetings in May combined general protestant concerns with the articulation of distinctive denominational interests. The United Presbyterians began in an irenic tone by observing that, apart from minorities and Irish immigration, Scotland had remained Presbyterian, which seemed to the organising committee 'to furnish a broad and easy basis for a united demonstration of the greatest event in its political and religious history'. The Synod also noted that this was the 'first public or formal celebration' of the Reformation owing to the 'dominance of antagonistic influences on the arrival of the first centenary, and of spiritual supiness on the arrival of the second', which had 'hindered its celebration at the one period and led to its neglect in the other' ${ }^{64}$ Yet the speeches delivered placed unity alongside denominational distinctiveness. The Revd William Anderson stated his opinion that 'our Reformers' had not been thorough in purging the Church of its defects and had multiplied terms of communion to 'a most exorbitant length'. ${ }^{65}$ Whereas this speech reflected the anti-establishment principles and modernising tendency of the United Presbyterians, the Church of Scotland emphasised its status as the established church of the Scottish people while the Free Church General Assembly became the vehicle for the articulation of James Begg's plans for the Scottish Reformation Society and it’s proposed Protestant Institute.

Yet there was an international dimension to the meeting of the Free Church that was not obvious in the other Presbyterian bodies. Important visitors from outside Scotland included Professor Peter Lorimer from London, Nicholas Murray (the noted 'Kirwan') from the United States, and Professor Robert Burns from Knox College, Toronto. Irish Presbyterians also took part, including William Gibson, now professor of Christian ethics at the Presbyterian College Belfast and moderator of the Irish General Assembly. Gibson's address noted the historical links between Scottish and Irish Presbyterianism and the unity of sentiment that was evident in the ongoing revival of religion in Ulster and Scotland in 1859 and 1860. Echoing J.S. Reid, he alluded to unity through the Solemn League and Covenant, which was 'taken all over the country with characteristic ardour, producing indeed kindred effects to those elsewhere experienced - uniting the friends of civil and religious liberty -

\footnotetext{
62 John Wolffe, The protestant crusade in Great Britain 1829-1860 (Oxford, 1991), 160-2, 249-50, 255-7, 262-3, 310-11.

${ }^{63}$ Coleman, 'Double-life of the Scottish past', 210-39.

${ }^{64}$ Caledonian Mercury, 16 May 1860.

${ }^{65}$ Glasgow Herald, 17 May 1860.
} 
strengthening attachment to the cause of Presbyterianism; and, better still, reviving those religious interests which had so lamentably declined under the sway of an antagonistic system, and amid the distractions and discouragements of intestine war' ${ }^{66}$ Gibson claimed the principles of the Scottish Reformation were destined to triumph on account of the ongoing religious revival and protestant missions to Catholics. In July a Free Church delegation attended the Irish General Assembly and reprised the historical links and the close connection between Presbyterian religion, patriotism, and prosperity. Robert Buchannan stated, 'They of the Free Church looked upon the Irish Presbyterian Church as the first-born of the Scottish Church, and as having done for Ulster what the Church of Knox and of Henderson had done for Scotland - making Ulster what it was, and marking it out pre-eminently on the map of Ireland as the seat of law and order, of intelligence and industry; and also as the seat of true religion and the fear of God. ${ }^{97}$

The tercentenary commemoration in August was an international event, yet the majority of the speakers at the Edinburgh meeting were from the Free Church. ${ }^{68}$ It was arranged by the Scottish Reformation Society and was not representative of mainstream opinion in Scotland. A variety of themes were covered at the meeting though the link between the Reformation and the constitutional development of Britain was a defining feature. According to Coleman, there 'could be no more profound declarations of the centrality of the Scottish Reformation to the constitutional freedoms of Victorian Britain than those made at this event. It was at the Scottish Reformation that the principles of constitutional monarchy that made Britain great had first been articulated, principles that were now victorious and universal, and whose essence must be maintained if the British nation was to remain true to its constitutional history. ${ }^{69}$ Reflecting upon the meeting, the Caledonian Mercury noted that the Reformation had been celebrated 'in a manner worthy of Scotland ... and in a way that has demonstrated to the thousands who were privileged to attend the meetings that the spirit which three hundred years ago gained for mankind the first fruits of civil and religious liberty is still alive in many lands, and that moral, social, personal, and political freedom can only be conserved to man by adherence to the truth as revealed in the Word of God.' The editorial was excited that the publication of the proceedings would inform the public about how the Reformation brought about 'civil and religious freedom' and 'the true principles of toleration - the law of protection of religious liberty'. The volume would show how events threehundred years ago ‘brought unalloyed good to Britain' in comparison with France, Spain,

\footnotetext{
${ }^{66}$ Caledonian Mercury, 25 May 1860.

${ }^{67}$ Belfast News-Letter, 5 July 1860.

${ }^{68}$ Coleman, 'Double-life of the Scottish past', 218-28

69 Ibid., 224-5.
} 
Italy, Hungary, and Poland where 'the peoples have been either plunged into cruel bondage or subjected to the ever-recurring miseries and terrors of revolution, anarchy, and despotism' ${ }^{70}$

The proceedings edited by James Aitken Wylie were published by the end of the year. The introduction was penned by Begg who described the Reformation as the second most glorious event in history after the advent of Christ. The ultimate results could only be read 'in the annals of eternity' but the practical results could be seen in the respective moral and social progress of Protestant and Catholic nations. Begg claimed that 'every intelligent and Christian Scotchman' had mixed feelings when looking back to the time of Knox for no sooner 'was our land freed from the enormous incubus of the Romish system, than a struggle for spiritual liberty commenced with our kings, and only terminated with the final overthrow of the infatuated race of Stuarts in 1688'. Significantly for a man who had some sympathy with Scottish nationalism, Begg was less than enthusiastic about the Union of 1707, noting that while it had brought 'temporal blessings', it 'had subjected our affairs to an uninformed and unsympathising Parliament, and been the means of tearing our Church to pieces'. He was particularly scathing about the brake on progress caused by a non-resident Scottish nobility, which had led to increased vice, crime, and poverty, as well as aristocratic conversions to Rome and the voting of public monies to Catholic institutions. Begg concluded by claiming that the active support of Catholicism and the apathy of many others to the distinctive principles of Protestantism were 'infallible symptoms of approaching evil'. ${ }^{71}$

Yet Begg's prognosis was not all gloom and he was quick to note that the recent revival of religion in Ireland and Scotland showed that God's cause was not lost. A number of Irish Presbyterian ministers were involved in the August event and reported on the progress of the 1859 revival and their efforts to convert Irish Catholics. ${ }^{72}$ While Irish Presbyterians focused on religious and social themes, Scottish speakers emphasised the inseparable connection between the Reformation, the British constitution, and Scottish patriotism. In a speech entitled 'God's truth and man's freedom', Thomas Guthrie noted that Knox, the Scottish Reformers, and the martyred Covenanters had not suffered in vain 'because they laid the foundations of our liberties deep in the Word of God. Therefore, we have a sovereign, but no slaves in this land; we have authority, but no oppression; we have rulers, but no tyrants; we have liberty without license, and religion without superstition: free trade, a free parliament, free justice, free thought; liberty, not the false, which is every man doing what he will, but the true, which is every man doing what he ought.' Focusing on Knox specifically, Wylie noted that by opposing Mary and preaching in St Giles, the reformer had 'fought the noblest battle

\footnotetext{
${ }^{70}$ Caledonian Mercury, 21 August 1860.

${ }^{71}$ J.A. Wylie (ed.), Ter-centenary of the Scottish Reformation, as commemorated at Edinburgh, August 1860 (Edinburgh, 1860), vii, xvii, xvii-xviii, xix. Begg's connections with Scottish nationalism are noted in Wolffe, Protestant crusade, 310-11.

${ }^{72}$ Wylie, Ter-centenary, 270-6, 287-91.
} 
ever waged upon Scottish soil, and defeated a more formidable foe than Wallace encountered at Stirling, or Bruce at Bannockburn'. Standing alone Knox had 'foiled the tactics of the most treacherous and cunning race of princes the world has ever seen', and had broken 'the firmknit leagues of Papal conspirators' in their vile designs for Scotland. By doing so, Knox’s fame had been secured: 'Through all the ages of the future, the foremost place among Scotsman must ever belong to Knox. He was the restorer of his country's faith, the founder of his country's liberties. ${ }^{73}$

In contrast with the August event, the December commemorations of the Reformation were national in coverage though the standard themes identified above were aired with regularity and on both side of the North Channel. Some speakers did offer novel interpretations, including the political theorist Patrick Edward Dove who offered a unique schematic discussion of Scottish constitutional history and how the struggle against oppression in various forms since Wallace and Bruce laid the basis for British civil and religious liberty. 'The principles of national unity had descended from Wallace and Bruce. There was, first, the principle of national independence - the Crown of Scotland not subject to any other Crown; 2d., the principle of the Reformation, the Bible above the Church, and above all human authority; 3d., the principle of the Covenanters, conscience above the King; 4th the principle of the Revolution - the King must reign according to law. ${ }^{74}$ The United Presbyterians rejoiced in the common principles of the Reformation but claimed that the Secession and Relief churches were the only denominations to fully uphold the principles of the Reformation - 'the spiritual nature of the Church of Christ', 'its absolute independence of control or support by the civil power', the 'exclusive and universal right' of church members to choose their own office holders, and their obligation to voluntarily support the clergy and missionary activity. ${ }^{75}$ The Irish General Assembly also set aside 20 December as a day of thanksgiving and recommended that 'the ministers of this Church on that day to call special attention to the aspects of the times in connexion with the movements of the Papacy'. ${ }^{76}$ The religious services held in Belfast and elsewhere throughout Ulster contrasted protestant liberty with Catholic tyranny and drew attention to the Scottish origins of the Irish Church. The Revd George Shaw of Alfred Street congregation in Belfast claimed that from the meeting of the first Scottish General Assembly on 20 December 1560, 'the Reformation took fast root in Scotland. On that Scottish Reformation and to that Scottish band Ulster largely owed the right, the truth, the liberty, and the peace which have long been the precious inheritance of her people. ${ }^{77}$ Likewise, the Revd James Warwick in Carrickfergus linked the religious

\footnotetext{
${ }^{73}$ Ibid. 10, 72-3.

${ }^{74}$ Coleman, 'Double-life of the Scottish past', 228-39, quotation 234-5

${ }^{75}$ Caledonian Mercury, 20 December 1860.

${ }^{76}$ MGA, ii (1860), 892.

${ }^{77}$ Banner of Ulster, 22 December 1860.
} 
Reformation of 1560 with the events of the Glorious Revolution, noting that the town was the scene of the first meeting of presbytery in June 1642 and William III's arrival in Ireland on 14 June $1690 .^{78}$

Both Scottish and Irish Presbyterians after 1860 continued to write Presbyterian histories of the Scottish Reformations and to commemorate such events as the tercentenary of the death of John Knox in November $1872 .{ }^{79}$ The concern with unity against the potential enemies of Presbyterianism culminated in the formation in 1876 of the Alliance of the Reformed Churches holding the Presbyterian System (later the World Alliance of Reformed Churches), a union of Presbyterians against 'infidelity and saceradotalism' ${ }^{80}$ Despite this concern, the relationship between Presbyterians in Scotland and Ireland came under increasing strain in the last quarter of the century. On the one hand, the fraught relations between the Free Church and the Church of Scotland had been overcome by the turn of the century. On the other hand, Presbyterians in Ireland were increasingly alarmed at the spread of critical attitudes towards the Bible in the Free Church, especially after the trial of William Robertson Smith. This was compounded by the ambivalent attitude of the Free Church towards Home Rule for Ireland. Free Church Presbyterians wanted to ensure Gladstone’s support for their campaign to disestablish the Church of Scotland and were thus unwilling to oppose his home rule proposals. It was against this backdrop that Presbyterians in Ireland reasserted their Scottish connections in an attempt to win support from their coreligionists for the unionist cause. ${ }^{81}$ This divergence should not, however, obscure the sense of unity that existed amongst Scottish and Irish Presbyterians in the Victorian era. It was based on a commitment to Presbyterian ecclesiology, evangelical Calvinism, and the practical out-workings of Presbyterian religion in the economic progress of their respective countries. It also gave both groups a sense of ownership of the United Kingdom by relating their shared experiences of the Scottish Reformations to the principles of religious and civil liberty. For them, Presbyterian principles provided the foundation of the British constitution.

\footnotetext{
${ }^{78}$ Banner of Ulster, 27 December 1860.

${ }^{79}$ Coleman, 'Double-life of the Scottish past', 239-49; Holmes, 'Irish Presbyterian commemorations', 57-8.

${ }^{80}$ MGA, v (1876), 102. J.D. Hoeveler, 'Evangelical ecumenism: James McCosh and the intellectual origins of the World Alliance of Reformed Churches’, Journal of Presbyterian History 55 (Spring 1977), 36-56.

${ }^{81}$ Holmes, 'Presbyterian religion, historiography and Ulster Scots identity’, 636-40.
} 